\title{
PERILAKU SOSIAL KEAGAMAAN PAGUYUBAN PENGAJIAN SEGORO TERHADAP PERAN SOSIAL DI KECAMATAN SUKOREJO KABUPATEN KENDAL JAWA TENGAH Oleh:
}

\author{
Andy Dermawan \\ UIN Sunan Kalijaga Yogyakarta \\ email: andy_derma@yahoo.com
}

\begin{abstract}
Abstrak: Perilaku keberagamaan masyarakat senantisa menarik untuk dikaji. Perilaku itu senantisa menggambarkan betapa dinamisnya perubahan sosial yang terjadi. Salah satunya contoh nyata dari hal itu adalah fenomena Paguyuban Pengajian Segoro di Sukorejo, Kendal. Melalui kajian berbasis pada kontektualisasi data manajemen berbasis sumber daya manusia, tulisan ini bertujuan untuk memberikan model pada proses perilaku sosial. Hasil penelitian ini menunjukkan bahwa perilaku sosial dan peran sosial di masyarakat ternyata memiliki akar kultur dan struktur yang sama, meski dilakukan dan diterapkan pada lembaga atau organisasi yang berbeda, tetapi nilai-nilai seperti tolong menolong, gotong royong dan musyawarah dalam masyarakat merupakan karakter dasarnya. Kalaupun terjadi perbedaan cara pandang, tidak sampai prinsipil, melainkan pada pola strategi pendekatannya.
\end{abstract}

Kata Kunci: Paguyuban Pengajian Segoro, Perilaku Sosial, Peran Sosial

\section{Pendahuluan}

Perilaku sosial keagamaan adalah perbuatan melaksanakan ajaran agama yang dilakukan dengan penuh keyakinan dan kesungguhan hati serta diimplementasikan di wilayah sosial masyarakat. Kontekstualisasinya dengan ajaran Islam, perbuatan itu merupakan bentuk penghayatan terhadap ajaran agama Islam yang dipelajari dan diamalkannya. Bukan hanya sekadar melaksanakan rutinitas ibadah sehari-hari melainkan lebih dari itu, yakni ativitas itu memiliki motif kuat di dalam menjalankan ajaran agama yang dimaknainya sebagai ibadah ke dalam bentuk keputusan tindakan sosial yang konkret dan bermakna bagi sesama dan lingkungannya. Inilah sesungguhnya perwujudan konkret iman dalam diri seseorang di dalam mengabdi kepada Allah., s.w.t. Ada sinergitas antara pelaksanaan ajaran agama dan tindakan sosial. 
Paguyuban Sekar Endahing Gotong Royong (biasa disebut SEGORO) merupakan salah satu kelompok pengajian berbasis jama`ah yang dinamis dan lahir dari berbagai macam status sosial. Mereka terdiri dari petani, pengojek, tukang sol sepatu, pembuat stempel, pemancing ikan, pegawai negeri sipil, tukang parkir, pedagang asongan pasar, pedagang makanan, komunitas orangorang terminal Sukorejo, anggota BPD, sarjana, dokter, guru ngaji, guru sekolah, komunitas haji, imam masjid dan bahkan ulama kampung setempat.

Ada empat hal problematik yang penting untuk ditelaah di Paguyuban Segoro. Pertama, hampir seluruh anggotanya datang dari berbagai status sosial di masyarakat, tentu terjadi dinamika pemikiran yang beragam dan perbedaan yang harus disinergikan. Kedua, secara manajemen pengorganisasian, ada integrasi antara visi individu dan visi organisasi (paguyuban), karena itulah komunitas tersebut mampu berjalan dinamis tanpa harus menghabiskan energinya untuk debat internal soal status sosial mereka. Ketiga, mereka datang dan memiliki kegelisahan sosial bersama, yakni bagaimana keberadaan mereka mampu berbuat lebih baik bagi kepentingan masyarakat. Misalnya, mereka merasa jenuh dengan tingkah polah kaum mudanya di masyarakat yang sebagian anak-anak mereka. Bagaimana kondisi mereka ke depan kalau kepedulian sosial itu tidak diwujudkan dari sekarang? Langkah bergabung dengan paguyuban pengajian inilah yang kemudian menjadi cara mereka berada, di samping keinginan untuk berbagi dengan sesama dalam status sosial yang berbeda. Keempat, cara masing-masing individu mempresentasikan peran sosialnya di masyarakat melalui media paguyuban pengajian tersebut.

Misalnya, komunitas orang-orang terminal Sukorejo yang mengadakan sunatan masal bagi masyarakat tidak mampu; kepanitiaan peringatan hari besar Islam (shalat ied, isra` mi `raj, maulud Nabi) dipercayakan kepada tukang parkir, orang-orang terminal, pedagang asongan, tukang mancing, guru, anggota BPD, dan ulama setempat yang menjadi anggota dari Paguyuban Pengajian Segoro.

Kontekstualisasinya dengan teori manajemen sumber daya manusia strategik menjelaskan bahwa penting melihat hubungan antara visi organisasi dan visi sumber daya manusianya (Mikhriani: 2004 dan Robert M. Grant: 
2001). Integrasi visi individu dan visi organisasi cenderung mampu membawa seluruh elemen organisasi mencapai tujuan yang dicita-citakan bersama.

Melalui penelitian ini, diharapkan ada alternatif model pemberdayaan pada setting sosial keagamaan yang dapat diterapkan pada komunitas lain di dalam mencapai tujuan bersama. Penelitian ini bertujuan untuk mengetahui dan memahami perilaku sosial keagamaan Paguyuban Pengajian Segoro terhadap peran sosial di masyarakat Sukorejo Kendal. Kegunaan penelitian ini memberikan solusi alternatif bagi paguyuban atau pengajian sejenis dalam kontribusinya membangun masyarakat yang berkemajuan dan menuju Islam yang sebenar-benarnya.

\section{Metode Penelitian}

Penting terlebih dahulu menyampaikan beberapa hasil penelitian yang berkaitan dengan tulisan ini. Tujuannya, adalah memastikan repositioning penelitian ini di antara penelitian-penelitian yang telah dilakukan. Penelitian M. Zainuddin berjudul Perilaku Sosial Keagamaan Dosen Agama Islam dalam Kehidupan di Masyarakat: Studi Atas Kompetensi Sosial Dosen-dosen Agama Islam Universitas Islam Negeri (UIN) Maulana Malik Ibrahim Malang. Penelitian ini menitikberatkan pada persoalan kontribusi para dosen agama Islam di lingkungan UIN Maulana Malik Ibrahim Malang di masyarakat yang terbagi menjadi tiga tipologi, yakni kontribusinya sebagai $d a \imath$, kontribusinya sebagai ustaz, dan kontribusinya sebagai tokoh masyarakat agama (kyai) (http://ejournal.uinmalang.ac.id/index.php/lemlit/article/view/367). Penelitian ini tidak menyinggung masalah peran sosialnya secara eksplisit, tetapi lebih pada persoalan perilaku sosial mereka di masyarakat.

Berikutnya, Pusat Pengkajian Islam dan Masyarakat (PPIM) melakukan penelitian Survei tentang Sikap dan Perilaku Sosial Keagamaan Guru-guru Agama di Jawa. Survei ini bertujuan memperoleh profil sosial keagamaan yang komprehensif guru-guru agama SMU di Jawa, kemudian ingin 
mendapatkan satu gambaran tentang pendidikan dan dinamika kehidupan keagamaan yang berlangsung di SMU di Jawa, dan menggali informasi dalam rangka perumusan kebijakan (policy paper) pengembangan guru-guru agama pada sekolah umum di Indonesia. Di antara temuan penting survei ini adalah bahwa guru-guru agama pada SMU di Jawa konservatif, jauh di atas masyarakat Jawa dan Indonesia pada umumnya. Temuan survei mengindikasikan bahwa guru-guru agama pada sekolah menengah umum cenderung memiliki sikap kependidikan yang mendukung agenda dan gagasan Islamisme. Temuan ini terlihat melalui dukungan terhadap pendidikan agama yang hanya berkonsentrasi pada penguatan sisi keagamaan-tidak diintegrasikan dengan kepentingan membangun negarabangsa-maupun pada dukungan terhadap praktik-praktik keagamaan di sekolah yang dilandasi semangat Islamisme. Penelitian ini hanya fokus pada perilaku sosial keagamaan saja dan keterkaitannya dengan dunia pendidikan menengah

(http://ppim.or.id/id/menu/ed_penelitian/detail.php?r=20121003000106sikap-dan-perilaku-sosial-keagamaan-guru-guru-agama-di-jawa).

Berdasakan paparan di atas, maka penelitian tentang perilaku sosial keagamaan Paguyuban Pengajian Segoro terhadap peran sosial di masyarakat Sukorejo Kendal Jawa Tengah penting dilakukan. Karena penelitian ini mencoba mengetengahkan dua hal, yakni perilaku sosial keagamaan dan peran sosial dalam masyarakat Islam.

Jenis Penelitian ini adalah penelitian lapangan (field research), tentang perilaku sosial keagamaan penganut Paguyuban Pengajian Segoro terhadap peran sosial di Kecamatan Sukorejo Kabupaten Kendal Jawa Tengah. Teknik pengumpulan data yang peneliti gunakan: 1) partisipatori, peneliti menjadi bagian yang diteliti dan terlibat langsung pada kegiatan atau perhelatan yang dilaksanakan oleh paguyuban tersebut. Penelitian ini bersifat kualitatif dan dasarnya adalah tindakan komunikatif (Mokhtar Bukhori, 1993). Dengan cara ini peneliti lebih leluasa mengamati fenomena di lapangan lebih dekat sehingga dapat memaksimalkan perolehan infomasi secara apa adanya dan 
meminimalisir terjadinya mispersepsi atau bias tafsir terhadap simbol dan tradisi yang benlaku di lapangan. Pada satu sisi juga peneliti tetap menjaga jarak (distance) antara peneliti dengan obyek sehingga relatif terjaga obyektifitasnya. 2) observasi, yakni melakukan pengamatan dan pencatatan secara sistematis atas gejala yang tampak (fenomena) pada obyek yang diteliti. Metode ini dilakukan dengan cara melihat langsung perilaku sosial keagamaan penganut Paguyuban Pengajian Segoro terhadap peran sosial di lokasi tersebut. 3) wawancara, sumber atau informannya adalah pengurus lembaga seperti ketua paguyuban pengajian, pengurus, anggota pengajian dan masyarakat. Level ketua, pengurus dan anggota adalah level para informan yang terlibat langsung pada kegiatan-kegiatan yang dilakukan lembaga, sedangkan level masyarakat adalah level untuk menggali data baik itu sebagai "pembanding" atau sekaligus media cross-check berkaitan dengan keakuratan data, dan 4) dokumentasi, mendokumentasikan data-data berupa catatan, bukubuku, gambar, atau informasi-informasi yang berkaitan dengan perilaku sosial penganut Paguyuban Pengajian Segoro terhadap peran sosialnya di masyarakat Sukorejo Kendal, maupun manuskrip lain yang berkaitan dengan penelitian. Selanjutnya, analisis datanya deskriptif-kualitatif, yakni memperoleh gambaran secara detail tentang perilaku sosial keagamaan lembaga tersebut terhadap peran sosial yang dilakukannya. Pendekatan keilmuannya, adalah integrasi-interkoneksi, yakni memadukan antara wilayah perilaku sosial dan wilayah perilaku keagamaan, dan interkoneksinya dapat dilihat dari pola hubungan penelitian ini dengan ilmu bantu-ilmu bantu lain lain seperti ilmu sosial, budaya, psikologi, pendidikan dan keilmuan keislaman. Berikutnya, interaksi-simbolik (interacsionism symbolic), yakni melakukan interaksi dengan subyek sekaligus memahami simbol-simbolnya (lihat juga L.J. Maleong: 1991 dan Robert Bogdan dan Steven J. Taylor: 1992).

\title{
Sketsa: Sukorejo dan Dinamika Sosial-Keagamaan
}

\author{
1. Sukorejo Kendal: Sebuah Sketsa
}


Sukorejo adalah desa-kecamatan yang terletak di ujung paling selatan dari Kabupaten Kendal. Meskipun Sukorejo sebuah desa, namun bisa dikatakan sebagai desa yang mulai "mengota" (beranjak menuju status kota) karena berkedudukan sebagai kecamatan. Bahkan dahulu pernah menjadi ibukota kawedanan Selokaton. Kecamatan Sukorejo sebelah Timur berbatasan dengan Kabupaten Temanggung dan sebelah Barat berbatasan dengan Kabupaten Batang (http://www.kendalkab.go.id/index.php/2012-0911-01-57-50/eksekutif/kecamatan/sukorejo/item/424-peta-wilayahkecamatan-sukorejo).

Melihat dari sejarahnya, Sukorejo menduduki peran strategis, baik secara ekonomi dan politik. Tempatnya tepat berada di tengah-tengah antara Kabupaten Temanggung, Kabupaten Batang dan Kabupaten Kendal, seolah merupakan daerah "segitiga" perlintasan perekonomian dan politik khususnya di Jawa Tengah. Dinamika masyarakatnya beragam. Bahkan hidup di tengah-tengah mereka etnis Tionghoa yang sudah mengakar puluhan tahun dan nyaris "bersenyawa" dengan "pribumi" setempat. Pandangan peneliti menggambarkan, tak tampak sekat etnis di kalangan mereka, sebagaimana hal itu terlihat dibeberapa wilayah di tempat atau kabupaten lain. Inilah pandangan unik dan mengesankan bagi peneliti untuk melihat lebih dalam dinamika masyarakat Sukorejo di tilik dari salah satu kegiatan masyarakatnya, yakni Paguyuban Pengajian Segoro.

Kini Sukorejo telah berubah menjadi "kota". Hampir semua perilaku perkotaan sejak dari cara berpikir dan keputusan tindakan melimpah ke sebagian masyarakat Sukorejo. Bisa ditebak, jika pada akhirnya ada sesuatu yang hilang, yaitu nilai-nilai luhur seperti gotong royong dan semangat kebersamaan menjaga wilayah tetap aman, tentram dan penuh nilai-nilai religiusitas itu mulai terhempas kepinggiran dan punah. Pada umumnya desa yang "mengota" berdampak adanya beberapa kebiasaan lama yang berlaku semenjak nenek moyang, mulai tergerus, hilang sedikit demi sedikit, di sadari atau tidak, meskipun kebiasaan itu kebiasaan yang baik, 
seperti kebiasaan bergotong-royong. Celah inilah yang, salah satunya, menyadarkan Paguyuban Pengajian Segoro mengenai arti pentingnya gotong royong sebagai nafas kehidupan bagi masyarakat "desa yang mengota".

2. Historisitas Paguyuban Pengajian Segoro: Dinamika Sosial-Keagamaan

Lahirnya Paguyuban Pengajian Segoro bukanlah didasarkan pada sekadar kerumunan atau sekelompok orang yang ingin membuat kegiatan di masyarakat. Lebih dari itu, yakni hadirnya sebuah kesadaran anggota kecil masyarakat yang mulai merasakan dampak modernisasi dan globalisasi yang menjarah tempat tinggal mereka. Tercerabutnya rasa solidaritas dan kebersamaan melalui media gotong royong mulai dirasakan dampaknya oleh mereka sehingga penting memiliki wadah sebagai ruang di dalam mengekspresikan niat baik itu dan mengapresiasi bentuk-bentuk kebaikan yang pernah ada di wilayah dan masyarakatnya. Tidaklah mungkin keisengan tanpa visi bisa lahir dan bertahan sekian tahun (kira-kira tahun 1995). Berangkat dari kebersamaan dan kesamaan visi, lahirlah misi dan tujuan untuk mengabdi kepada masyarakat melalui cara mereka, yakni membuat suatu perkumpulan yang bermanfaat bagi masyarakat.

Awal mulanya, ada sekelompok orang yang menaruh kepedulian terhadap hilangnya kebiasaan bergotong royong. Mereka adalah kelompok orang-orang yang gemar memancing ikan, kadang di sungai dan kadang di laut. Sambil menunggu ikan memangsa umpannya itu ada salah seorang yang mempunyai gagasan mendirikan semacam perkumpulan untuk melestarikan kegiatan gotong-royong itu meskipun dalam lingkup kecilkecilan dan dalam batas-batas tertentu. Kemudian gagasan itu disampaikan kepada teman-teman lainnya, gagasan itupun disepakati. Akhirnya didirikanlah suatu paguyuban yang diberi nama "SEGORO" (Wawancara Mas`as Mukhtar Hadi, 2013) . 


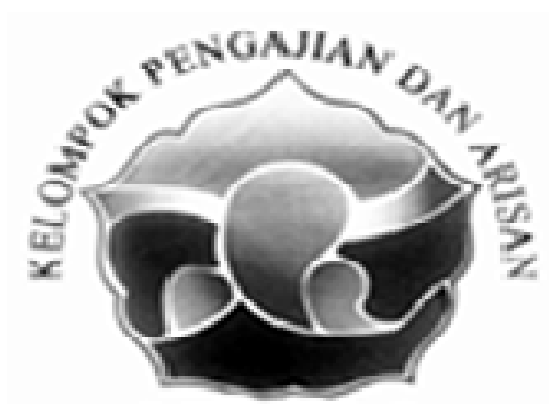

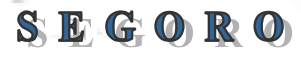

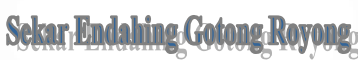

Kata SEGORO kependekan dari Sekar Endahing Gotong Royong. Maksud dan pengertian secara luasnya adalah Indahnya kebersamaan saling tolong menolong. Kata yang menandakan suatu community identity dalam struktur masyarakat tertentu merupakan suatu ikhtiar yang tidak sekadar iseng atau main-main. Penetuan kata itu tentu lahir dari rasa kebersamaan dan mewujud dalam suatu kegiatan yang bermanfaat bagi masyarakat pada umumnya. Mereka merencanakan membuat lambang yang sederhana, yang menggambarkan profil komunitas. Lambang itu diberi makna dan memberi arahan visi dan misi bagi seluruh elemen yang ada di dalamnya. Penjelasan wujud lambang tersebut sebagai berikut (Data Profil Pengajian Segoro, 2013).

Pertama, garis pinggir terdiri dari lima kurung kurawal sebagai lambang lima rukun Islam. Kedua, kurung kurawal dipadu dalam satu rangkian, sehingga menimbulkan lima bentuk sudut runcing ke dalam dan lima bentuk sudut runcing ke luar. Ketiga, lima sudut runcing yang mengarah ke dalam merupakan harapan agar lima rukun Islam tersebut dapat membentuk kepribadian dan menjadi penghayatan hidup bagi masingmasing anggotanya. Keempat, lima sudut runcing yang mengarah keluar merupakan harapan agar kepribadian dan penghayatannya itu bisa realisasikan sebagai amal salih yang bermanfaat bagi lingkungan masyarakat di mana masing-masing anggotanya berada. Kelima, kurung kurawal adalah lambang solidaritas, kebersamaan dalam skala besar sehingga sebagai muslim tetap dalam kesatuan tanpa membedakan pemahaman ajaran madzhab, tanpa membedakan organisasi kemasyarakatan/keagamaan dan organisasi politik, tanpa membedakan status sosial bagi masing-masing anggotanya. Keenam, lintasan garis yang sedikit melengkung menggambarkan gerak air yang tidak menimbulkan 
gelombang besar. Air merupakan kebutuhan vital bagi semua makhluk hidup, termasuk manusia di dalamnya. Oleh karenanya air dalam arti kesegaran atau kenikmatan perlu disalurkan sampai ketepian menjangkau mereka yang sangat membutuhkan. Ketujuh, gambar ikan atau kepala ikan yang diminimalisir merupakan kenangan historis, dari mana awal mula ide paguyuban SEGORO itu muncul. Bermula dari idenya orang-orang yang mempunyai hobi mancing ikan. Berjam-jam mereka sering berada di tengah laut di atas perahu sewaan, kepanasan dan kadang-kadang kehujanan menunggu ikan menyantap mangsanya sebagai resiko orang mancing.

Salah satu hal menarik dari paguyuban ini adalah jama`ahnya. Mereka datang dari berbagai kelompok sosial, strata sosial dan status sosial yang berbeda-beda, seperti PNS, pekerja ojek, buruh, juru parkir, pengurus BPD, pedagang kaki lima, pengusaha, dan dokter. Bisa dibayangkan, kesamaan status sosial saja belum tentu membuat satu kelompok tertentu itu harmoni, tapi ini multi-status sosial. Di sinilah pentingnya menelaah lebih dalam cara mereka mengekspresikan diri di tengah keragaman dalam satu paguyuban, melalui perilaku sosialnya di masyarakat. Bisa dibayangkan, ketika masingmasing latar belakang para jamaah yang berkumpul dalam satu ikatan kelompok paguyuban dan berkontribusi secara bersamaan terhadap lingkungannya, tentu cukup memberi pandangan bahwa menyatukan banyak pikiran itu tidak mudah.

Paguyuban Pengajian Segoro lahir oleh karena keperihatinan sebagai anggota masyarakat yang mulai merasakan pudarnya kebersamaan dalam konteks tolong menolong, nilai Islam menegaskan ta`awanu `ala albirri wa at-taqwa, saling tolong menolong dalam kebaikan dan ketaqwaan. Tolong menolong dalam konteks keindonesiaan adalah semangat gotong royong, sebagai nilai yang melekat dalam masyarakat Pribumi Nusantara. Perbedaan tentu terjadi di kalangan mereka, tetapi cara merespon dan bersikap pada suatu masalah, itu merupakan suatu hal yang penting untuk dilakukan secara baik. 
Apa yang terjadi di kelompok masyarakat atau paguyuban yang lain, yakni keluar dan masuknya beberapa anggota, juga terjadi di lingkungan Paguyuban Pengajian Segoro. Hal itu wajar, karena setiap individu memiliki keterbukaan untuk mengekspresikan diri dalam organ-organ di masyarakat, apapun nama dan bentuk kelompoknya. Termasuk harus diakui beberapa permasalahan yang kadang tak mampu diurai oleh salah satu anggota di lingkungan Paguyuban Pengajian Segoro, sehingga mengakibatkan ada anggota yang keluar, meski juga ada yang datang dan masuk sebagai anggota baru. Inilah bukti suatu organisasi itu sehat, bahwa perbedaan dan masalah yang secara internal terjadi bukanlah aib atau hal buruk, melainkan suatu dinamika organisasi yang menampung sejumlah orang dan memiliki perbedaan satu di antara lainnya. Bersikap terhadap perbedaan, itulah pelajaran mahal bagi semua orang bahwa suatu kelompok organ di masyarakat termasuk Paguyuban Pengajian Segoro merupakan "laboratorium sosial" di dalam membangun diri agar lebih baik lagi dan bermakna serta bermanfaat bagi sesama, khairu an-nas `anfa`uhum li annas, sebaik-baik manusia adalah yang bermanfaat bagi manusia lain.

Dengan demikian dapat dipahami, perilaku sosial yang dilakukan mereka sesungguhnya tidak terlepas dari visi dan misi lembaga tersebut yang menginternal dalam diri mereka sendiri. Visinya, adalah "Sesuai dengan esensi sekar (kembang) mempersiapkan manusia yang berkepribadian dengan mengedepankan iman dan taqwa demi terwujudnya lingkungan sehat, menyejukkan serta mampu memberikan kontribusi penting terhadap masyarakat luas".

Misinya adalah, membiasakan berfikir sehat, memupuk solidaritas dan bersikap toleran terhadap perbedaan pemahaman, terutama pemahaman ajaran Islam yang sering muncul di tengah-tengah masyarakat, menyalurkan profesionalitas masing-masing sesuai dengan kemampuan yang ada kepada yang membutuhkannya demi membantu terlaksananya kesejahteraan masyarakat di lingkungannya, membiasakan diri untuk menyalurkan sebagian rejeki kepada orang lain tanpa pamrih, kecuali semata-mata untuk 
mensyukuri nikmat yang diberikan Tuhan, dan menyadarkan diri bahwa manusia adalah makhluk sosial, yang tidak bisa hidup sendiri, namun pasti membutuhkan bantuan orang lain, apapun bentuk bantuannya.

Beberapa program dan kegiatannya antara lain, arisan yang dilakukan bukan arisan sebagaimana umumnya arisan dimana masing-masing anggota menerima hak dari hasil uang arisannya sesuai dengan kesepakatan para pesertanya. Arisan di Paguyuban Pengajian Segoro sebenarnya lebih mirip disebut sebagai tabungan infaq, karena nantinya uang arisan tersebut disalurkan untuk kepentingan sosial, terutama para anggotanya. Kegiatan rutin bulanan yang dilakukan, sekedar memberi santunan bulanan, kepada warga yang dipandang sangat membutuhkan. Karena keterbatasan dana maka untuk sementara diutamakan hanya beberapa fakir miskin yang ada dilingkungan dekat anggota paguyuban. Kegiatan rutin tahunan, tepatnya setiap Idul Fitri, membagi bingkisan lebaran kepada anak yatim, fakir miskin dan mengadakan khitanan masal manakala belum ada ormas atau kelompok lain yang menyelenggarakannya. Berikutnya, adalah kegiatan temporer. Kegiatan ini dilakukan apabila ada bencana alam, seperti gunung meletus, gempa bumi, banjir bandang dan lain sebagainya. Kontribusi seluruh anggota jama`ah Pengajian Segoro bersegera mengulurkan bantuan baik berupa materi maupun non-materi.

Kegiatan ke dalam hampir tidak pernah mengalami kendala yang berarti. Kendala yang paling dirasakan bahwa paguyuban ini belum mempunyai kantor dan karyawan sehingga ketika ada orang berkepentingan dengan paguyuban, hanya bisa lewat perorangan anggotanya, sementara jawaban atau keputusan masih harus menunggu minggu depan setelah pertemuan rutin. Kendala lain, meski skala kendalanya tidak besar, hanya menambah kerja di luar program, seperti ketika Paguyuban Pengajian Segoro akan mengantarkan sumbangan bencana alam. Mestinya sumbangan Paguyuban Pengajian Segoro bisa disampaikan cukup dengan mobil kecil, tetapi karena banyak yang tahu dan akhirnya banyak yang titip, seperti ketika mengantar sumbangan bencana alam Gunung Merapi dan gempa di 
Yogyakarta tahun 2006. Karena banyak titipan sembako yang harus disampaikan, akhirnya terpaksa harus menggunakan tiga mobil truk besar, padahal sebetulnya satu mobil kecil saja sudah cukup. Menurut Bapak Mas`as:

"Meskipun para anggota Segoro itu datang dari berbagai status sosial dan strata sosial di masyarakat, setiap ada kegiatan selalu dilaksanakan secara bersama-sama (kroyokan). Banyak hal baik telah kami lakukan. Berkaitan dengan kelompok atau organisasi yang lain, biarlah masyarakat yang menilai. Yang penting bagi Segoro adalah ketika kami masih bisa dan sempat membantu masyarakat yang membutuhkan tenaga dan pikiran Segoro..., kami siap berkontribusi. Karena itu sebagian besar kegiatan kami arahkan untuk memberi dan berkontribusi kepada mereka..." (Wawancara Mas`as Mukhtar Hadi, senin 14 Oktober 2013).

Secara partisipatoris, realitas masyarakat itu merupakan "laboratorium alam" bagi pengembangan masyarakat. Kelompok Paguyuban Pengajian Segoro berfungsi sebagai tempat jamaah mengadu, menceritakan, klarifikasi masalah-masalah keagamaan, dan mendesain masyarakat muslim yang mengamalkan Islam yang sebenar-benarnya. Langkah teknisnya bisa bermacam-macam, salah satunya bersama-sama jamaah mengidentifikasi problematika yang dihadapi dan mengurainya berdasarkan akar masalahnya. Sebagai "laboratorium alam", Paguyuban Pengajian Segoro adalah "rumah dinamis" bagi para penghuninya sekaligus kolektor problematika masyarakat untuk didiskusikan dan diurai akar masalahnya. Para jama`ah belajar menjelaskan problematika, mengidentifikasi masalah, mengorek pengetahuan, dan mencari sumber informasi untuk dimengerti akar persoalannya. Jika jamaah sudah terbiasa mengkomunikasikan apa yang mereka alami, tentu akan memberi kemudahan untuk membantu pemecahannya (Andy Dermawan: 2009, bab II dan III, lihat juga Alef Theria Wasim, 2005).

\section{Perilaku Sosial dan Peran Sosial: Problematika Jama`ah}

Menurut Hasan Mustofa dalam tulisannya berjudul Perilaku Manusia dalam Perspektif Psikologi Sosial, menjelaskan, bahwa re-inforcement adalah proses di mana akibat atau perubahan yang terjadi dalam lingkungan 
memperkuat perilaku tertentu di masa datang. Misalnya, jika kapan saja kita selalu tersenyum kepada orang asing (yang belum kita kenal sebelumnya), dan mereka tersenyum kembali kepada kita, maka muncul kemungkinan bahwa jika di kemudian hari kita bertemu orang asing maka kita akan tersenyum. Perlu diketahui, reinforcement atau penguat, bisa bersifat positif dan negatif. Contoh di atas merupakan penguat positif. Contoh penguat negatif, misalnya beberapa kali pada saat kita bertemu dengan orang asing lalu kita tersenyum dan orang asing tersebut diam saja atau bahkan menunjukan rasa tidak suka, maka dikemudian hari jika kita bertemu orang asing kembali, kita cenderung tidak tersenyum (diam saja). Pendekatan perilaku menjelaskan teori-teori secara mendalam, mengapa fenomena sosial yang diutarakan dalam pendekatan perilaku bisa terjadi (Hasan M: journal.unpar.ac.id/index.php/JABCebis/article/view/156).

Tokoh lain yang mencoba diutarakan oleh Hasan Mustofa, bahwa sosok Albert Bandura, mengusulkan satu perbaikan atas gagasan Miller dan Dollard tentang belajar melalui peniruan. Bandura dan Walters menyarankan bahwa kita belajar banyak perilaku melalui peniruan, bahkan tanpa adanya penguat (reinforcement) sekalipun yang kita terima. Kita bisa meniru beberapa perilaku hanya melalui pengamatan terhadap perilaku model, dan akibat yang ditimbulkannya atas model tersebut. Masih menurut Hasan Mustofa, proses belajar semacam ini disebut observational learning atau pembelajaran melalui pengamatan.

Contohnya, percobaan Bandura dan Walters mengindikasikan bahwa ternyata anak-anak bisa mempunyai perilaku agresif hanya dengan mengamati perilaku agresif sesosok model, misalnya melalui film atau bahkan film karton. Bandura menyarankan agar teori pembelajaran sosial mestinya diperbaiki lebih jauh lagi. Dia mengatakan bahwa teori pembelajaran sosial yang secara an sich menggunakan pendekatan perilaku dan lalu mengabaikan pertimbangan proses mental, perlu dipikirkan ulang. Bandura menegaskan, sebagaimana dijelaskan Hasan Mustofa, bahwa teori pembelajaran sosial membahas tentang bagaimana perilaku kita dipengaruhi 
oleh lingkungan melalui penguat (reinforcement) dan observational learning, cara pandang dan cara pikir yang kita miliki terhadap informasi, dan begitu pula sebaliknya, bagaimana perilaku kita mempengaruhi lingkungan kita dan menciptakan penguat (reinforcement) dan observational opportunity-kemungkinan bisa diamati oleh orang lain (Ibid. Lihat juga James A.Wiggins, Beverly B. Wiggins, dan James Vander Zanden, 1994 dan Abdul Munir Mulkhan, 1995).

Perilaku sosial merupakan fakta nilai di masyarakat. Nilai itu berkembang seiring dengan perkembangan perilaku sosial individu sebagai anggota masyarakat yang berproses di dalam menemukan aktualisasi dirinya. Demikian juga dengan nilai yang ada di Paguyuban Pengajian Segoro. Sebut saja salah satu nilai organisasinya adalah gotong royong.

Gotong royong merupakan perilaku sosial yang menonjol di kalangan anggota Paguyuban Pengajian Segoro, bahkan nama itu menjadi core nama organisasi yang merumahinya. Penjelasan lain yang penting diperhatikan, secara sosial mereka inklusif dan toleran terhadap hal-hal baik meski berbeda dengan visi dan misi Paguyuban, sebaliknya jika hal itu berkaitan dengan aqidah, sudah barang tentu mereka tetap tegas dan istiqamah di dalam menjaga dan menjalaninya.

Sikap-sikap toleran dan inklusif cenderung diutamakan Paguyuban sebagai salah satu dasar nilai dan strategi di dalam "mendidik" umat agar tetap solid, istiqamah pada kebaikan, dan tegas pendirian pada aqidah dari rongrongan Dunia Global dan arus teknologi informasi dewasa ini. Menurut bapak Mas`as Mukhtar Hadi, seorang ulama yang mendampingi masyarakat sekaligus tokoh spiritual kampung Sukorejo dan Paguyuban Pengajian Segoro menyatakan,

"Memahami tipologi masyarakat itu mesti dengan hati dan pemahaman tentang mereka dengan jernih. Kita tidak bisa memaksakan sepenuhnya atau melepas secara longgar sepenuhnya pula. Mereka punya perilaku yang dikonstruksi sosial dan lingkungannya. Ada tarik-ulur dalam hal ini. Karena pemahaman masyarakat tentang pengetahuan keagamaan khususnya perlu kehati-hatian dan strategi yang pas dan tidak 
menyinggung banyak pihak. Agar tujuan kita secara bersama tercapai baik, maka perlu memastikan metode dan pendekatan kepada mereka. Mereka adalah manusia, dan cara mendekatainya tentu dengan kemanusiaan. Itulah mengapa hampir setiap ada perhelatan di masyarakat atau yang diadakan oleh anggota Paguyuban khususnya, saya selalu usahakan bisa hadir. Dari sini, kita bisa mengamati pola pikir, perilaku dan sikap mental mereka..., atau perilaku sosialnya" (Wawancara pada 15 Oktober 2013).

Wawancara di atas menjelaskan bahwa perilaku sosial di masyarakat khususnya perilaku sosial anggota Paguyuban Pengajian Segoro menjadi alasan penting untuk memahami seberapa kuat dan berpengaruh peran sosialnya. Maka dari itu bapak Mas`as Mukhtar Hadi senantiasa mengamati secara baik personal identity yang ada sebagai langkah metodis pemberdayaannya di masyarakat melalui Paguyuban tersebut. Inilah peran partisipatoris-aktif yang dilakukan sebagai bentuk pemberdayaan dan kepedulian terhadap jamaah dan masyarakatnya. Hasil dari proses pemberdayaan itu terlihat dari salah satu komentar anggota Paguyuban,

"Bisa kumpul-kumpul begini, keuntungan bagi aku, sehingga aku tidak putus sedulur, apalagi kumpul-kumpulnya ini bawa manfaat bareng"(Wawancara dengan bapak Kusnun di Sukorejo, pada 15 Oktober 2013).

Wawancara tersebut menunjukkan bahwa ada perubahan mendasar pada diri masyarakat dalam hal ini salah satu anggota Paguyuban. Perubahan itu adalah kesadaran akan pentingnya hidup dalam kebersamaan dan melakukan kebaikan secara bersama-sama pula. Perilaku sosial demikian, kecil kemungkinan mewujud tanpa adanya pendampingan dan pemberdayaan secara terus-menerus, sehingga menjadi pola hidup dan terbangun karakter baik. Dari sini jelas, bahwa perilaku sosial di masyarakat itu terbangun salah satunya melalui pola pemberdayaan dan pendampingan melalui media organisasi, kelompok atau paguyuban yang berorientasi pada pengembangan diri dan kemaslahatannya bagi umat. Sebaik-baik manusia adalah yang bermanfaat bagi manusia lain, khairu an-nas anfa uhum li an-nas.

Proses pendampingan dan pemberdayaan yang dilakukan di Paguyuban Segoro terlihat bahwa perilaku sosial anggota Paguyuban Pengajian segoro 
mampu menunjukkan bukti pada masyarakat Sukorejo akan dampak positifsosial yang dirasakan hasilnya oleh masyarakat. Contohnya perilaku sosial keagamaan berupa sikap santun, keinginan menolong atau membantu sesama dan serius memperhatikan kehidupan spiritualitasnya.

Berdasarkan analisis peneliti di lapangan, memang tidak semua terbangun kesadarannya, sebab semua mesti berproses sebagaimana sunnatullah. Meski demikian, hampir sebagian sependapat bahwa mereka mengalami perubahan cukup signifikan ketika masuk sebagai anggota Paguyuban. Mereka merasa ada sinergitas antara cara dan tujuan di dalam menjalani kehidupan di dunia. Runtuhnya batas ideologi pribadi, status sosial, dan strata sosial di kalangan mereka ternyata menjadi energi dan potensi kuat di dalam menggalang persatuan di antara mereka.

Stephen P. Robbins berpendapat, ada tiga level dalam mengembangkan dan mempelajari perilaku manusia dalam organisasi melalui tiga tingkatan analisis yaitu: pertama, Tingkatan Individu yang menjelaskan tentang karakteristik bawaan individu dalam organisasi; kedua Tingkatan Kelompok, yang menjelaskan tentang dinamika perilaku kelompok dan faktor-faktor determinannya; dan ketika Tingkatan Organisasi, yang menjelaskan tentang faktor-faktor organizational yang mempengaruhi perilaku (http://perilakuorganisasi.com/perilaku-organisasi-po.html dan Stephen P. Robbins: 2002, edisi ke-5).

Paguyuban Pengajian Segoro memiliki nilai-nilai organisasi yang merupakan akumulasi antarindividu atau antaranggota paguyuban. Nilai-nilai itu menjadi acuan dalam berpikir dan bertindak (perilaku) di masyarakat. Beberapa rangkaian nilai-nilai paguyuban seperti gotong royong, kebersamaan, semangat persatuan dan tolong menolong merupakan dasar nilai utamanya. Nilai gotong royong dapat dilihat pada peristiwa-peristiwa menyedihkan yang menimpa masyarakat atau anggota paguyuban, misalnya gempa bumi di Yogyakarta, banjir dan salah satu anggota Paguyuban yang sakit dibantu dari patungan atau urunan guna membantu yang bersangkutan. 
Berikutnya nilai kebersamaan, menjadi nilai utama para anggota paguyuban. Kebersamaan itu dapat disaksikan dari tertib dan keinginan kuat menghadiri undangan-undangan musyawarah dan rapat anggota yang dipergilirkan disetiap rumah warga sebagai anggota paguyuban. Kemudian, nilai semangat persatuan yang ditunjukkan lewat perhelatan-perhelatan acara hari Besar Islam yang dilakukan secara kroyokan (red. bersama-sama) agar acara tersebut sukses, lancar dan maslahat bagi semua yang hadir.

Terakhir, nilai tolong menolong. Nilai itu diwujudkan melalui kegiatan-kegiatan yang menghasilkan dana baik dari arisan atau sumbangan dari beberapa warga dan anggota paguyuban. Seperti, bantuan orang sakit, fakir miskin dan tertimpa musibah.

Beberapa kegiatan Paguyuban Pengajian Segoro sukses di masyarakat tidak hanya ditentukan oleh perencanaan yang matang, tetapi oleh karena tindakan afektif dari anggota paguyuban. Tindakan afektif merupakan bentuk luapan spontanitas sebagai dampak dari emosi seseorang ketika merasakan problem yang dihadapi masyarakat. Luapan itu bisa bermacam-macam dampaknya, seperti rasa spontanitas melakukan kegiatan sosial, menyumbang dan berbagi rejeki dengan fakir miskin tanpa direncanakan sebelumnya, tergerak menolong seseorang yang sedang dirundung duka. Intinya, tindakan afektif itu tanpa di dasari oleh "perencanaan intelektual" dan spontanitas oleh gerakan dari dalam diri. Anggota Paguyuban Pengajian Segoro rata-rata memiliki afektifitas, rasa menolong dan keinginan tinggi membantu orang lain menyegera di dalam kehidupannya sehari-hari. Menurut Haedar Fahmi, sebagian besar anggota Paguyuban Segoro itu cenderung cekatan dan tanpa pikir panjang dalam membantu masyarakat,

"Anggota Paguyuban Segoro yang saya ketahui selama ini, memiliki sensitifitas sosial dan afektifitas tinggi di dalam merespon masalahmasalah kemanusiaan. Apalagi hal itu menyangkut soal umat, seperti gotong royong, membantu yang fakir dan miskin serta kegiatan-kegiatan sosial..., mereka spontanitas bergerak membantu...”. 
Tindakan afektifitas dalam organisasi tidaklah bisa disebut serampangan tanpa perencanaan matang, juga tidak bisa dikatakan tanpa pertimbangan dan persiapan sebelumnya. Tindakan afektif merupakan panggilan "dari dalam", ia adalah luapan emosi yang diakibatkan oleh sesuatu yang bersifat internal dan eksternal. Itulah cara cepat tanggap di dala mereaksi suatu masalah. Dalam organisasi tindakan afektif dibutuhkan. Meski harus diakui, tindakan perencanaan juga merupakan hal penting untuk dilakukan. Semua tergantung dari permasalahannya, dan elan fital permasalahan itu bergantung juga pada sistem di masyarakat. Sistem yang dimiliki masyarakat cukup elegan karena mampu membuat masyarakat beradaptasi dengan perubahan lingkungannya. Masyarakat secara dinamik difasilitasi oleh sistem sosialnya dapat melakukan peningkatan kesejahteraan dan kebutuhan sosialnya (Soetomo: 2002, 72; lihat juga George Ritzer: 2012, 214 dan MC. Ricklefs: 2007).

Kehadiran Paguyuban Pengajian Segoro adalah penanda bahwa masih ada sekelompok masyarakat di wilayah Sukorejo yang masih memiliki kepedulian, perhatian, dan rasa tanggungjawab terhadap linkungannya. Hadirnya rasa berketuhanan dirasa oleh semua anggota ketika mereka menjadi anggota paguyuban. Tentu ada alasan mendasar mereka melakukan hal itu. Salah satu anggota yang juga bertanggungjawab Bendahara-I Paguyuban Pengajian Segoro menyatakan,

"Saya baru paham kalau ajaran Islam itu sebetulnya gampang. Sebab selama ini Islam yang saya dengar itu sepertinya berat, sukar mengerjakannya, karena salah sedikit saja kena dosa, sedikit-sedikit haram dan seterusnya. Di segoro ini ternyata ada pengajian Islam dan Islamnya dirasakan gampang, meskipun tidak boleh digegampang seenaknya sendiri“ (Wawancara dengan Bapak Zaeri di Sukorejo pada tanggal 20 Oktober 2013).

Pandangan di atas menunjukkan, bahwa pengertian Islam itu damai, pasrah dan berserah diri kepada Allah., s.w.t, mampu dirasa oleh para anggota salah satunya Pak Zaeri. Tentu setelah mendapatkan pemahaman melalui 
kegiatan pengajian di kelompok Paguyuban tersebut. Keinginan bergabung dengan Paguyuban Pengajian Segoro mampu mengantarkan dirinya pada suatu pemahaman bahwa berislam itu ternyata membuat hidup dirinya menjadi lebih mudah dan bertanggungjawab.

Menurut Azis Muslim, paradigma pengembangan masyarakat Islam menjelaskan, bahwa kemiskinan, kebodohan dan keterbelakangan masyarakat itu terjadi disebabkan oleh paradigma masyarakat yang kurang berorientasi pada potensi dan kemandirian sumber daya manusia. Paradigma pengembangan masyarakat yang berorientasi pada model pertumbuhan ekonomi telah membawa masyarakat ke jurang kebodohan, kemiskinan, keterbelakangan dan kenestapaan jiwa spiritualitas mendalam. Memandang manusia atau masyarakat sebagai subyek dalam pengembangan masyarakat menjadi sangat penting dalam rangka memanusiakan manusia. Proses humanisasi pada gilirannya mampu mendorong manusia untuk berpartisipasi aktif dalam proses pengembangan masyarakat. Pengembangan masyarakat yang fokus dan sumber utamanya manusia akan dapat mengubah peranan masyarakat sebagai penerima pelayanan yang pasif menjadi anggota masyarakat yang mampu berperan aktif dalam pembangunan (Azis Muslim: 2005, 10-12).

Azis menjelaskan lebih lanjut, bahwa potensi manusiawi yang paling penting dalam pengembangan masyarakat adalah kemampuannya bermusyawarah. Musyawarah membawa perubahan pada pelakunya. Kemampuan baru akan lahir dan watak pribadi akan berkembang dan musyawarah akan melahirkan pengalaman-pengalaman baru, selain menggerakkan hati juga menggerakkan kehendak untuk lebih baik lagi (Azis Muslim: Jurnal PMI, Vol. 1, No. 1, 2003).

Inilah konteks perilaku sosial yang sesungguhnya lahir dari keinginan baik dalam diri masyarakat itu sendiri. Arah pengembangan masyarakat pada hakikatnya diarahkan untuk meningkatkan harkat dan martabat serta kualitas sumber daya manusia atau masyarakat, yaitu manusia yang beriman dan bertaqwa kepada Allah Swt, berakhak mulia, berpengetahuan, sikap dan nilai- 
nilai serta keterampilan yang diperlukan bagi pengembangan diri dan masyarakat. Tujuannya jelas, yakni terwujudnya masyarakat mandiri, maju yang dapat memenuhi kebutuhan hidupnya sehingga menjadi masyarakat yang sejahtera dan bahagian lahir dan batin (Abu Suhud: 2003, 29-30, lihat juga A. Suyadi: 1989).

\section{Penutup}

Perilaku sosial paguyuban pengajian Segoro, adalah suatu bentuk tindakan sosial yang diwujudkan adanya saling ketergantungan satu sama lain dan merupakan sifat kemanusiawian manusia. Manusia di dalam memenuhi kebutuhan hidup tidak dapat melakukannya sendiri melainkan memerlukan bantuan orang lain. Individu sebagai anggota masyarakat dituntut mampu bekerjasama, saling menghormati, dan toleran dalam hidup bermasyarakat. Itulah yang mewujud dalam cara berpikir, sikap mental dan perilaku.

Peran sosial Paguyuban Pengajian Segoro adalah rangkaian perilaku serta harapan seluruh anggota paguyuban yang dilakukan dan dipenuhi sebagai warga masyarakat Sukorejo Kendal di dalam memastikan arah aktualisasi diri. Kecenderungan sosial yang dilakukan oleh Paguyuban Pengajian Segoro adalah suatu tindakan sosial untuk melakukan perubahan. Status sosial Paguyuban Pengajian Segoro di dalam masyarakat dinilai dari peranannya di masyarakat seperti penguatan spiritualitas melalui pengajian, gotong royong, mengentaskan kemiskinan dan tolong menolong. Rasa tanggungjawab sosial Paguyuban Pengajian Segoro merupakan bentuk kepedulian dan cara berada di masyarakat.

Dengan demikian, maka perilaku sosial Paguyuban Pengajian segoro terhadap peran sosial di masyarakat adalah suatu tindakan sosial yang berbasis nilai-nilai paguyuban pengajian sebagai cara berada di masyarakat yang dibuktikan dengan peranan sosialnya sebagai wujud eksistensinya di tengah masyarakat sukorejo. Hasil penelitian ini menunjukkan bahwa perilaku sosial dan peran sosial di masyarakat ternyata memiliki akar kultur 
dan struktur yang sama, meski dilakukan dan diterapkan pada lembaga atau organisasi yang berbeda, tetapi nilai-nilai seperti tolong menolong, gotong royong dan musyawarah dalam masyarakat merupakan karakter dasarnya. Kalaupun terjadi perbedaan cara pandang, tidak sampai prinsipil, melainkan pada pola strategi pendekatannya.

\section{Daftar Pustaka}

Bogdan, Robert, dan Steven J. Taylor, 1992. Pengantar Metoda Penelitian Kualitatif; $\quad$ Suatu Pendekatan Fenomenologis Terhadap Ilmu-ilmu Sosial, terj. Arief Furchan, Surabaya: Usaha Nasional.

Bukhori, Mochtar. 1993. Riset Partisipatoris Riset Pembebasan, Jakarta: Gramedia.

Dermawan, Andy. 2009. Ibda` Binafsika: Menggagas Dakwah Partisipatoris, Yogyakarta: PT. Tiara Wacana.

--------------------, 2009. Dialektika Islam dan Multikulturalisme di Indonesia: Ikhtiar Mengurai Akar Konflik, Yogyakarta: PT. Kurnia Kalam Semesta.

Maleong, L.J. 1991. Metodologi Penelitian Kualitatif, Bandung: Remaja Rosdakarya.

Mikhriani, 2004. "Rumusan Strategik dan Keunggulan Kompetitif dalam Manajemen Sumber Daya Manusia Unggul", dalam Makalah, dipresentasikan pada Program Doktor Ilmu Ekonomi, Universitas Islam Indonesia.

Mulkhan, Abdul Munir. 1995. Teologi Kebudayaan dan Demokrasi Modernitas, Yogyakarta: Pustaka Pelajar.

Muslim, Azis. 2005. "Paradigma Pengembangan Masyarakat: Konsep Makro Kesejahteraan Sosial", dalam Suisyanto dkk, Islam, Dakwah dan Kesejahteraan Sosial, Yogyakarta: Jurusan PMI bekerjasama dengan IISEPCIDA.

, 2003. "Konsep Dasar dan Pendekatan Pengembangan Masyarakat", dalam Jurnal PMI, Fakultas Dakwah UIN Sunan Kalijaga Yogyakarta, Vol. I, Nomor I, September. 
Ricklefs, MC. 2007. Polarising Javanese society: Islamic and Other Visions, Singapore: NUS Press.

Ritzer, George. 2012. Teori Sosiologi: Dari Sosiologi Klasik sampai Perkembangan Terakhir Postmodern, terj. Saut Pasaribu, Rh. Widada, Eka Adinugraha, Yogyakarta: Pustaka Pelajar.

Soetomo, 2002. Keswadayaan Masyarakat: Manifestasi Kapasitas Masyarakat untuk Berkembang Secara Mandiri, Yogyakarta: Pusaka Pelajar.

Strauss, Anselm, dan Juliet Corbin, 1997. Dasar-dasar Penelitian Kualitatif; Prosedur, Teknik, dan Teori Grounded, terj. H.M. Djunaidi Ghony, Bina Ilmu: Surabaya.

Suhud, Abu. 2003. "Pendekatan Andragogi dalam Pengembangan Masyarakat", dalam Jurnal PMI, Fakultas Dakwah UIN Sunan Kalijaga Yogyakarta, Vol. I, Nomer I, September.

Suyadi, A. 1989. Dakwah Islam dan Pembangunan Masyarakat Desa, Bandung: CV. Mandar Maju.

Wasim, Alef Theria (ed.). 2005. Religious Harmony: Problems, Practice and Education, Yogyakarta: Oasis Publisher.

Weber, Max. 1949. The Methodology of The Social Sciences, New York: The Free Press.

Wiggins, James A., Beverly B. Wiggins, dan James Vander Zanden, 1994. Social Psychology, McGraw-Hill, Inc.

http://ejournal.uin-malang.ac.id/index.php/lemlit/article/view/367

http://ppim.or.id/id/menu/ed penelitian/detail.php?r=20121003000106-sikap-danperilaku-sosial-keagamaan-guru-guru-agama-di-jawa

http://dehazel.blogspot.com/2013/04/v-behaviorurldefaultvmlo.html,diunduh pada selasa 12 November 2013.

http://perilakuorganisasi.com/perilaku-organisasi-po.html

http://galihdanary.wordpress.com/2010/12/06/teori-perilaku-sosial-max-weberteori-sosiologi-klasik/, diunduh pada Selasa 12 November 2013.

http://www.organisasi.org/1970/01/daftar-nama-kecamatan-kelurahan-desakodepos-di-kota-kabupaten-kendal-jawa-tengah-jateng.html. Diunduh pada Senin 18 November 2013, jam 14.15. 